time furnished the vaccinators with lymph cultivated on bulls which were intended for slaughter; he inoculated them on the scrotum. Chauveau has also successfully vaccinated bulls, and so have other experimenters. Roloff, of the Berlin Veterinary School, has demonstrated how easily the bull could be infected. He slightly abraded the skin of the scrotum, and gently rubbed the vaccine lymph upon it; the characteristic eruption took place in due course. If bulls or bullocks stood in cattle-sheds with an equal number of cows, and were treated and exposed to contagion in the same way as these, there is every probability that we should have bull- or bullock-pox frequently enough. Where this association is allowed to take place on the Continent, bulls and bullocks are infected. An interesting case of this kind is recorded in the Repertorium für Thierheilkunde for 1879. $A$ bull, two and a half years old, is there described as affected with vaccinia, the pustules and crusts being situated on the scrotum, a hind and fore foot, and lips. The animal suffered a good deal. The lymph from the pustules was employed with success in the vaccination of children. So that it is simple nonsense to assert that the male bovine is exempt from vaccinia; and it betrays ignorance of what has been observed by competent men, as well as lack of knowledge of pathology in general and this disease in particular. (To be continued.)

\section{WOOD'S OPERATION FOR RADICAL CURE OF SCROTAL HERNIA; COMPLETE CURE.}

BY F. C. BARKER.

A HEALTHY-LOOKING Hindu vagrant lad of twenty was admitted in October, 1879, into the Surat Civil Hospital for the relief of hernia. He had been in hospital previously for the removal of preputial chancres by circumcision, and for fever. The hernia was a year old, readily reducible, and as easily caused to descend by position and coughing. It was said to have been acquired during a straining effort from dysentery, followed by faintness, and a fall in which the right leg was extended into a neighbouring hole. The inner and outer inguinal rings were about three-quarters of an inch apart.

The operation was performed on Oct. 11 th with chloroform, an assistant keeping up the intestine. The wires (copper, plated with silver) were crossed over the pad, according to the directions of surgical manuals, but the lower one was brought through a special slit made for its exit higher up than the scrotal incision, as the latter, from its direction, would have been kept agape from a wire drawing up one of its sides.

The wires were drawn out by an assistant on the tenth day after operation, some sloughing having meanwhile taken place of the cellular tissue of scrotum and groin, and of a patch of scrotal skin ${ }^{1}$ below the incision with a pretty sharp febrile movement for the first day after operation, a fetid black discharge with gaseous gurgling following on the second. After this a gradual cleansing, aided by carbolic lotion injections, took place. On subsidence of the sloughing action a long sinus was left, uniting all three wounds; this was completely laid open with a bistoury on the twentyfirst day and its floor discovered to be composed of the invaginated tissues properly adherent in their new situation and undisturbed by violent coughing, which also did not interfere with the tucked-up position of the testicle. This wound quickly contracted under cleansing and disinfecting treatment and carbolic oil dressing, and finally cicatrised under a thick scab formed by applications of caustic on the 2nd and 3rd December.

He was discharged on the 15 th December with the wound quite healed, testis still tucked-up and of natural size, and no descent of hernia on standing and coughing.

1 This proved favourable to a good after result, from the reduction caused in the size of the scrotum.

Vaccinatron Grant.-Mr. Philip E. Hill, Crickhowell Union, has for the second time received a grant from the Local Government Board of $11217 \mathrm{~s}$. for successful vaccination in his district.

\section{g attirtor}

\section{HOSPITAL PRACTICE, BRITISH AND FOREIGN.}

Nulla autem est alia pro certo noscendi via, nisi quamplurimas et morborum et dissectionum historias, tum aliorum, tum proprias collectas habere, et inter se comparare.-MorGaGri De Sed. et Caus. Morb., lib. iv. Procmium,

\section{CHARING-CROSS HOSPITAL.}

POPLITEAL ANEURISM; FAILURE OF PRESSURE; LIGATURE OF FEMORAL ARTERY; RAPID RECOVERY; REMARKS.

(Under the care of Mr. BELLAMY.)

For the following notes we are indebted to $\mathrm{Mr}$. Harris, dresser at the hospital.

John K- was admitted on Oct. 30th, 1879, with popliteal aneurism. He was a strong, healthy-looking man, and had been in the army for five and a half years, and left it August 10th, 1876. From that time he had been a gentle. man's servant. He had been a moderate drinker, but had had no previous illness until three years before, when he contracted syphilis, followed in a few months by secondary symptoms. On leaving the military hospital he caught a severe cold, which brought on an attack of rheumatic fever, which lasted five months. On New-year's eve, 1878, he was decorating a room with evergreens when he fell from a pair of steps-a height of about six feet-on to his feet. His legs bent under him, and he sprained his wrist against a wall From that time he felt no pain until Oct. 2lst, 1879, when he found that his knee hurt him, and the pain was referred to the popliteal region, where a swelling appeared. He had been walking rather more than usual, but could not remember that he had given himself any particular strain.

On admission there was a regularly circumscribed tumour in the popliteal region, about the size of a large pigeon's egg, which pulsated excentrically. When the common femoral artery was compressed, the pulsation ceased, and the tumour could be emptied. On removing the compression the blood rushed into the tumour with a coarse-blowing sound, and on listening with the stethoscope the bruit was found to be synchronous with the ventricular systole. The man complained of pain, which was diffused around the knee-joint, and was steadily increasing in severity, and extending downwards into the leg.

The sac of the aneurism being very thin and rapidly getting larger, the application of Esmarch's elastic bandage was tried on November 4 th, for four days for about thirty minutes every four hours.

There was no appearance of the formation of a clot, and the tumour became larger, the pulsation greater, the sac much thinner. Mr. Bellamy, therefore, determined to ligature; and on the $6 \mathrm{th}$, after allowing the patient some rest from the previous treatment, he tied the superficial femoral artery antiseptically, using a strip of a bullock's aorta, as recommended by Mr. Barwell.

The patient slept fairly well, and did not complain of pain next morning. There was no return of pulsation in the tumour, nor could any be felt in either of the tibial arteries. On the Sth there was absence of pulsation in the sac, and consolidation was taking place. On the 13 th there was still absence of pulsation. The sutures were removed, and the edges of the wound brought together by strapping. On the 19th the ligature seemed to have become absorbed. There was, for the first time, slight pulsation in the anterior tibial artery, but only a "flicker;" the leg was warm. On the 24th, antiseptic dressing was discontinued, the wound was healed and the sac devoid of pulsation. The patient was allowed to get up; and on the $27 \mathrm{th}$, he left the hospital at his own request.

Remar7s. - In a subsequent clinical lecture Mr. Bellamy remarked on the rapid development of the aneurism, and its evidently rapid increase during the time the elastic bandage had been applied. The object in using the bandage in this case was rather to develop the collateral circulation than to induce consolidation in the sac, and the result showed that this was speedily accomplished, the temperature of both limbs being the same throughout the treatment, and the continuation of the pressure would probably have burst it. 